\title{
Working
}

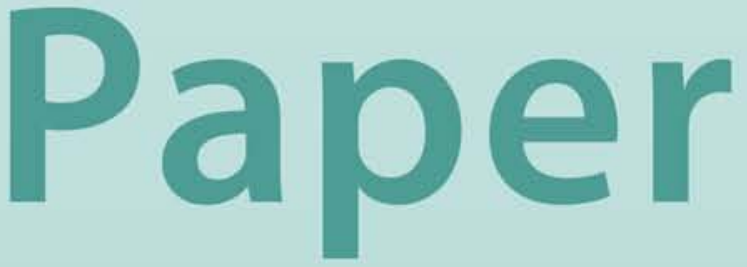


Strengthening Chile's Rule-Based

Fiscal Framework

Teresa Dabán 
(C) 2010 International Monetary Fund

\title{
IMF Working Paper
}

Western Hemisphere Department

\section{Strengthening Chile's Rule-based Fiscal Framework}

\author{
Prepared by Teresa Dabán ${ }^{1}$
}

Authorized for distribution by Robert Rennhack

January 2011

\begin{abstract}
This Working Paper should not be reported as representing the views of the IMF.

The views expressed in this Working Paper are those of the author(s) and do not necessarily represent those of the IMF or IMF policy. Working Papers describe research in progress by the author(s) and are published to elicit comments and to further debate.

The cornerstone of Chile's impressive fiscal performance has been its structural balance rule. By insulating public spending from short-term copper price fluctuations and the business cycle, the rule has helped preserve fiscal discipline. However, the implementation of the rule in recent years has revealed certain challenges, and in May 2010, the government established a high-level commission to recommend reforms that could make the rule even more effective. This paper assesses the scope for improving the design and implementation of the structural balance rule in light of best practices and OECD country experience with fiscal rules. This assessment suggests several options to strengthen Chile's fiscal rule, including by simplifying the calculation of the structural balance; enhancing the rule's flexibility, transparency and accountability; and complementing it with a medium-term fiscal framework.
\end{abstract}

JEL Classification Numbers: E01, E60, H6, Q3

Keywords: Fiscal rules, structural balance, resource revenue management, resource curse, public financial management, transparency, accountability, resource-producing countries.

Author’s E-Mail Address:tdaban@imf.org

\footnotetext{
${ }^{1}$ The author is especially grateful to Robert Rennhack, Dora Iakova, and Nicolas Magud, who has extensively commented on the paper. She also thanks to the large number of colleagues from FAD and WHD, who have provided valuable comments, and especially to Mauricio Villafuerte, Xavier Debrun, and Rodrigo Valdés. The author also thanks the participants on the WHD seminar held on November 3, 2010 and the MCD seminar held on December 16, 2010.
} 


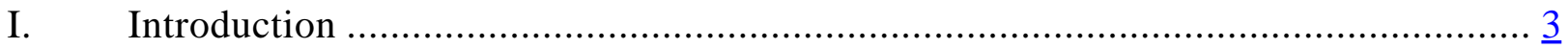

II. Background: Chile’s Main Fiscal Challenges and Risks …............................. $\underline{3}$

III. An Assessment of Chile's Fiscal Rule................................................... $\underline{5}$

IV. Options to Strengthen Chile’s Fiscal Rule.............................................. 15

V. Conclusions and Summary ............................................................ 20

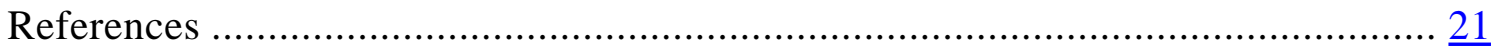

Figures

1. Central Government's Assets and Liabilities ......................................... $\underline{3}$

2. Copper Price Evolution and Composition of Mining Revenues ............................ $\underline{9}$

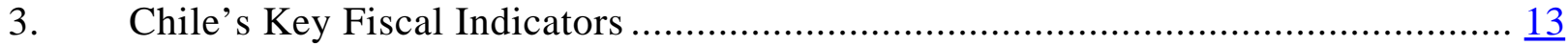

4. Structural Copper Revenues and Expenditures Under Alternative

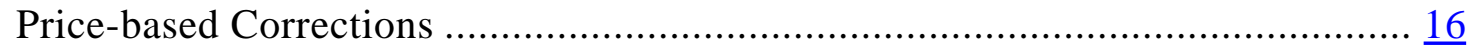

Tables

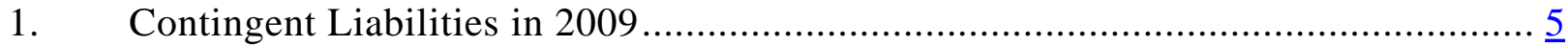

2. Modifications to the Methodology of Calculation of the Structural

Balance, 2005-10................................................................................. 10

3. Chile's Fiscal Balances .................................................................... 11

4. Assessment of Chile’s Structural Balance Rule .......................................... 12

5. Management of Ex-post Deviations from Fiscal Rules in Selected

OECD Countries ......................................................................... 17

6. Escape Clauses of Fiscal Rules in Selected OECD Countries............................. 18

7. Fiscal Councils in Selected OECD Countries.............................................. 19

Appendixes

1. Chile’s Copper Sector ....................................................................... 23

2. Chile's Fiscal Rule from an OECD Perspective ......................................... 24 


\section{INTRODUCTION}

The cornerstone of Chile's impressive fiscal performance has been its structural balance rule. By insulating public spending from shortterm copper price fluctuations and the business cycle, the rule has helped preserve fiscal discipline. However, the implementation of the rule in recent years has revealed certain challenges, and in May 2010, the government established a high-level commission to recommend reforms that could make the rule even more effective. This paper assesses the scope for improving the design and implementation of the structural balance rule in light of best practices and OECD country experience with fiscal rules. This assessment suggests several possible options to strengthen

Figure 1. Central Government's Assets and Liabilities (In percent of GDP)

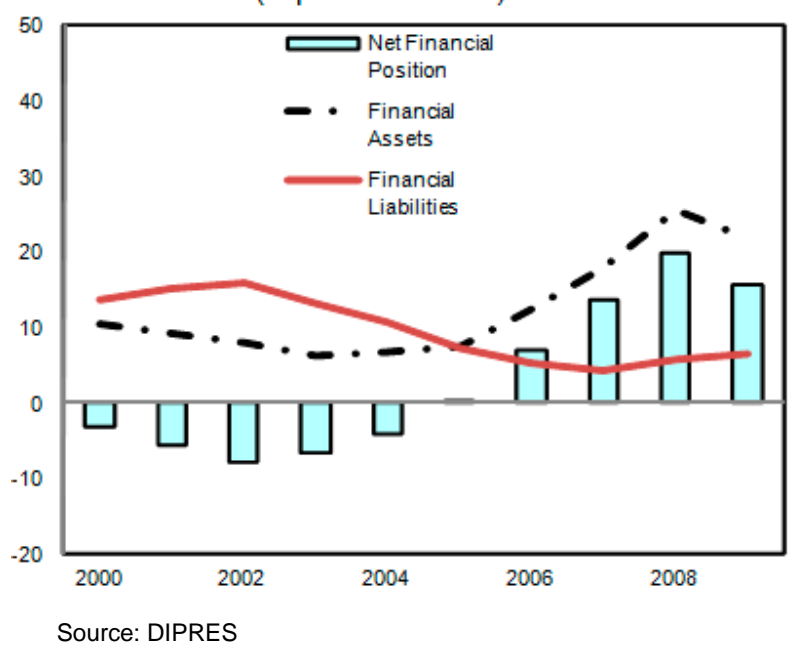

Chile's fiscal rule, including by simplifying the calculation of the structural balance; enhancing the rule's flexibility, transparency and accountability; and complementing it with a mediumterm fiscal framework.

The structure of the paper is as follows. Section II provides an overview of how the structural balance rule has helped Chile to address its main fiscal challenges and risks. Section III assesses Chile's structural balance rule, from three complementary angles, including the rule's de jure design, the rule's de facto operational implementation, and a comparison with OECD practices. Section IV outlines options to strengthen Chile's structural balance rule. Section E concludes.

\section{BACKground: ChILE’S MAIn Fiscal Challenges AND Risks}

Chile's economy remains highly vulnerable to external shocks, but especially to volatility in copper prices. Shocks include sharp exchange rate changes, natural disasters, as well as terms of trade fluctuations, among others. But one of Chile's most important fiscal challenges, by far, is managing the volatility of copper tax revenues, especially given the large and increasing amount of revenues that the government derives from the copper sector (see Appendix I). While during 2000-04 copper revenues accounted for only 5 percent of total revenues (around 1 percent of GDP), in the last five years copper revenues have increased significantly and accounted for 24 percent of total government revenues (or almost 6 percent of GDP). If fully spent in real time, copper revenues would have put pressure on absorptive capacity and triggered pressures for a sizable real appreciation of the currency.

To address these challenges, since 2001, the authorities have put in place the structural balance rule. The rule built on the copper stabilization fund adopted in the late 1980s, which allowed government spending to evolve in line with sustainable copper revenues, valued at the 
long-term copper price. In 2001, the government added an adjustment for the business cycle and defined the structural balance as the central government balance evaluated at potential output and the long-term copper price. In 2002, committees of experts were designated to provide independent, technical estimates of potential output and the long-term copper price. The government then set a target for the structural balance in line with a goal for accumulation of net financial assets. The rule allowed the central government to fend off spending pressures and run large surpluses as copper prices surged. At the end of 2008, the central government's financial assets equaled 20 percent of GDP, while financial liabilities accounted for only 6 percent of GDP, with a total net financial position equivalent to 26 percent of GDP (see Figure 1).

The structural balance rule was also aimed at providing long-term savings to cover Chile's contingent liabilities, which at present still remain sizeable. ${ }^{2}$ The main contingent liabilities include the (i) the recognition bonds introduced in the 1980s after the privatization of the pension system; (ii) the minimum pension guarantee introduced in 2008; (iii) government guarantees of borrowing by state-owned enterprises; (iv) minimum revenue and exchange rate guarantees under public-private partnership arrangements; (v) banking deposit guarantees; (vi) judicial lawsuits; and (vii) a miscellaneous of programs that provide guarantees to loans and mortgages issued by commercial banks to students, small business, and other collectives. The estimated costs of these contingent liabilities, when adjusted by expected associated risks, amounted to 13 percent of GDP in 2009. However, this estimation could be higher if the liabilities associated to the negative capital of the central bank and commitments under the fuel price stabilization funds are included. The contingent liabilities' expected costs would also increase if estimations are conducted at the maximum risk level and the contingent liabilities related to the minimum pension guarantee are computed by using the net present value of the expected future flows (see Table 1).

\footnotetext{
${ }^{2}$ Since 2003 Chile has included information on contingent liabilities in its fiscal accounts. Since November 2007following the requirement of its 2006 Fiscal Responsibility Law-it has also issued a stand-alone annual report on contingent liabilities that provides information on the amount, expected maturity, type of guarantee and beneficiaries of the government's explicit contingent liabilities, i.e., those that are defined by law or contract. However, the report does not provide an estimation of the government's implicit guarantees, i.e., those guarantees that derive from a moral or expected obligation, based on public expectations or pressures. The government's main implicit contingent liabilities derived from the expectation that (i) the government would maintain fuel prices at a stable level (e.g., the government has intervened in recent years with sizeable capital injections in its two fuel price stabilization funds, the FEPCO and FEPP, see DIPRES (2009)); and (ii) the Ministry of Finance would address the recapitalization of the central bank.
} 
Table 1: Chile: Contingent Liabilities in 2009

\begin{tabular}{|c|c|c|c|c|c|}
\hline & \multicolumn{5}{|c|}{ (In percent of GDP) } \\
\hline & $\begin{array}{c}\text { Maxium Risk } \\
\text { Level } \\
\end{array}$ & Methodology & $\begin{array}{c}\text { Adjusted Risk } \\
\text { Level 2/ }\end{array}$ & $\begin{array}{c}\text { Methodology } \\
2 / \\
\end{array}$ & Probability \\
\hline Recognition Bonds & 7.7 & NPV & 7.7 & NPV & High \\
\hline Minimun Pension Guarantee & 17.5 & NPV & 0.9 & Annual Flow & High \\
\hline PPP Guarantee & 4.2 & NPV at max. risk & 0.2 & NPV adjt. Risk & Moderate \\
\hline Banking Deposit Gurantee & 2.8 & NPV at max. risk & 1.8 & NPV adjt. Risk & Low \\
\hline SOE debt guarantee & 1.6 & NPV face value & 1.6 & NPV face value & High \\
\hline Others 1/ & 0.6 & $\begin{array}{l}\text { Annual Flow } \\
\text { BCCh's negative }\end{array}$ & 0.6 & Annual Flow & Low/Moderate \\
\hline Undercapitalization central bank & 2.5 & $\begin{array}{c}\text { capital } \\
\text { Average }\end{array}$ & $\ldots$ & $\ldots$ & Moderate \\
\hline Petroleum Prices Stabilization Funds & 0.2 & Contribution & $\ldots$ & $\ldots$ & Moderate \\
\hline Total & 37.1 & & 12.8 & & \\
\hline
\end{tabular}

\section{An Assessment of ChILE’S Fiscal RULE}

This paper assesses Chile's structural balance rule from three different but complementary angles: (i) from the optic of best practices on the design of fiscal rules; (ii) the practical implementation of the rule; and (iii) vis-à-vis the most common practices and approaches used by OECD countries.

\section{Best practices on the design of fiscal rules}

According to best practices, rule-based fiscal frameworks are characterized by a set of distinct features. A fiscal rule is defined as "a mechanism placing some durable constraints on fiscal discretion through numerical limits on budgetary aggregates (expenditure, revenue, budget balance and/or public debt)" (see Kumar and Ter-Minassian (2007)). However, there is no one-size-fits-all fiscal policy rule that is always and everywhere ideal. The design of a fiscal rule depends on the constellation of shocks prevalent in an economy, the nature and magnitude of the fiscal policy bias under discretion, and the main fiscal challenges ahead.

The abundant literature on fiscal rules identifies a core set of critical components of a welldesigned fiscal rule (IMF, 2009 and Kopits and Symansky, 1998). These include:

(i) Clear, and as simple as possible, set of operating fiscal variables, including a numerical target or ceiling (or a combination thereof) defined in terms of a specific fiscal indicator (or a combination thereof); a clear definition of the fiscal objectives or challenges the rule aims at addressing, which should be consistent with other macroeconomic policies; and an unambiguous and stable link between the numerical targets or ceilings and the ultimate fiscal objectives. 
(ii) Sufficient flexibility to respond to shocks, which are beyond the authorities' control, so that the rule should not exacerbate the adverse macroeconomic impact of shocks (permanent or transitory). The rule should provide ex-ante sufficient room for a stabilizing fiscal response and a gradual adjustment to the fiscal targets, while avoiding procyclicality and preserving credibility. The flexibility provisions would include, "exceptional circumstances clauses" that allow for temporary deviations in the face of major shocks; well-defined mechanisms to deal with ex-post deviations; and provisions to undertake periodic and rolling adjustments of the numerical targets.

(iii) Clear and well-designed institutional arrangements, which should include a clear statutory basis; effective management and monitoring mechanisms, to prevent and assess deviations from the numerical targets or ceilings; transparency and accountability provisions, to make it explicit the cost incurred by policymakers if they deviate from the rule; and enforcement procedures, to ensure policymakers incur costs when deviations occur.

How does the "de jure" design of Chile's structural balance rule compare with best practices?

Chile's fiscal rule is supported by a solid and highly hierarchical institutional

arrangement. Since 2006, the implementation of Chile's structural balance rule is supported by legislation, the Fiscal Responsibility Law (FRL). ${ }^{3}$ This gave a more solid legal foundation for the rule adopted in 2001, which had been based on a high-profile political commitment. ${ }^{4}$ The FRL mandates that the President must adopt, within the 90 days of taking office, "a decree defining the fiscal fundamentals of his/her administration and the expected impact on the structural balance.” This reflects Chile's institutional arrangement, according to which, compared with other Latin American and OECD countries, most fiscal powers are vested in the President and the executive branch (IMF, 2003, 2005). According to the constitution, the President alone may take fiscal initiatives, which congress can only approves or rejects. The constitution prohibits congress from increasing or lowering the revenue estimates in the draft budget; it may only reduce draft expenditures—as long these are not allocated by a permanent law. If congress does not approve the annual budget law within 60 days after submission by the President, the draft budget automatically comes into force. ${ }^{5}$ Under this hierarchical system, fiscal discipline depends excessively on the commitment of a relatively small group of actors (see Blondal and Curristine (2004) and Marcel, et al. (2001)).

\footnotetext{
${ }^{3}$ Law 20128 of Fiscal Responsibility, approved in September 2006.

${ }^{4}$ The decision to implement the structural balance rule in 2001 was taken after the overall central government balance for 1999 showed a 2 percent of GDP deficit for the first time in 10 years (see Fiess, 2001). It was perceived as highly credible, even though the rule was not mandated by law.

${ }^{5}$ According to Blondal and Curristine (2004), "in Chile congress enjoys very limited powers in the budget process. It simply appears to be accepted across the political spectrum that congress would act irresponsibly in the budget area if it were given any substantive power."
} 
The FRL defines clearly the nature and coverage of the structural balance, The target of Chile's fiscal rule, i.e., the structural balance, is defined as "the balance that the central government would have achieved if the economy was operating at potential, i.e. excluding the effect that the cyclical fluctuations in economic activity, the copper price, and other factors of similar nature, may have on the government revenues and expenditures” (Article 16 FRL, 2). The definition of the structural balance excludes the central bank and public enterprises but includes the central government's interest payment and interest receipts. Therefore, the structural balance is the measure of the central government's discretionary fiscal policy.

The FRL provides no guidance on the practical implementation of the rule. The FRL indicates in its Article 16 that "the Budget Directorate (also known as DIPRES in Spanish) would compute the structural balance according to the methodology, procedures, and other applicable norms that would be established by a Supreme Decree of the Ministry of Finance". However, this Supreme Decree on the methodology of the structural balance has not been enacted yet.

The FRL does not define the objectives of the rule. Instead, the FRL focuses on the use of fiscal surpluses, if generated by the implementation of the rule. Moreover, it authorizes the Ministry of Finance to allocate 0.5 percent of GDP per year, during 2006-11, for the recapitalization of the central bank provided the central government runs an overall surplus. It also creates two sovereign funds: (i) the Pension Reserve Fund (PRF), aimed at covering future (after 2016) commitments on minimum pensions; the PRF is funded with a minimum annual contribution of 0.2 percent of GDP (to be made even in the case of overall deficit), which can be increased to 0.5 percent of GDP; and (ii) the Economic and Social Stabilization Fund (ESSF), which replaced the Copper Stabilization Fund, and was designed to compensate for drops in revenue in periods of slower growth and/or lower copper prices, and to finance any future deficits as an alternative to borrowing. The ESSF's resources will come from any central government overall surpluses (after the contributions to the PRF and the transfers for the recapitalization of the central bank have been done). Resources from the ESSF can be used to fund the contributions to the PRF when the overall central government balance is negative.

\section{The FRL does not include an explicit provision to respond to major shocks nor envisage} any provision to handle temporary ex-post small deviations. In principle, Chile's rule is very flexible because it allows the government to modify the structural balance target at any time. Indeed, the target has been changed on two occasions, in 2008 and in 2009, when circumstances required a change. However, the FRL does not specify the circumstances under which the structural balance target could be changed, the procedures that need to be followed to introduce these changes or the process to return the fiscal accounts to normal. In fact, once a target value for the structural balance is specified, the rule becomes extremely rigid, with no ex-ante and transparent "escape clauses.” Moreover, the FRL does not specify whether the compliance of the rule should apply to ex-ante estimates or ex-post outcomes or envisage any mechanism to correct small ex-post deviations. These small deviations may take place because of forecast errors in the estimation of structural revenues, which usually are very sensitive to most recent data and revisions to historical data. 
The FRL includes important provisions on the monitoring and transparency of the rule, but leaves out any formal verification process. The most salient aspects of the FRL are (i) requiring the Budget Directorate to compute the structural balance each year; (ii) allowing the government to rely on independent experts for non-binding judgments on the long-term copper price and the key inputs for potential output; ${ }^{6}$ and, (iii) requiring the Budget Directorate to issue an annual report on the government's contingent liabilities. However, the FRL does not provide for the monitoring and reporting of the actual structural balance or for independent third party verification of the compliance with the rule.

\section{Implementation of Chile's structural balance}

In practice, the nature, rationale and even the methodology of the structural balance rule are usually laid out in policy papers of the Budget Directorate. A 2001 policy paper of the Budget Directorate (see Marcel et al. (2001)) outlined for the first time Chile's structural balance rule. The paper noted that the structural surplus targeted with the rule (1 percent of total GDP at the time) was to be used to recapitalize the central bank, pre-finance contingent liabilities, and create a buffer of net financial assets to allow the central government to absorb external shocks. The paper also noted that the rule was designed "to allow the automatic stabilizers in the budget to work uninhibited, while reducing the procyclicality of the fiscal policy, avoiding fine-tuning of fiscal policy to the phases of the cycle, and isolating the economy from transitory shocks." However, the rule, as defined in the policy paper, does not include an explicit debt ceiling or a floor for the government's net financial position that could help provide a medium-term anchor.

The initial methodology devised by the Budget Directorate to compute the structural balance was relatively easy to understand. The initial methodology devised in Marcel et al. (2001) consisted in (i) estimating ex-ante the expected structural revenues $\mathrm{E}\left(\mathrm{SR}_{\mathrm{t}}\right)$, i.e., the revenues that the government would have achieved if the economy was operating at potential and the copper price was at its long-term level; (ii) subtracting from the expected structural revenues the structural balance $\left(\mathrm{SB}_{\mathrm{t}}\right.$, e.g., a 1 percent of GDP surplus as originally envisaged in 2001); and (iii) calculating the expenditures $\left(\mathrm{E}_{\mathrm{t}}\right)$ as a residual, according to the following formulae:

$$
\begin{gathered}
\mathrm{E}_{\mathrm{t}}=\mathrm{E}\left(\mathrm{SR}_{\mathrm{t}}\right)-\mathrm{SB}_{\mathrm{t}} \\
\mathrm{E}\left(\mathrm{SR}_{\mathrm{t}}\right)=\mathrm{E}\left(\mathrm{R}_{\mathrm{t}}\right)-\mathrm{E}\left(\mathrm{A}_{\mathrm{t}}\right)=\mathrm{E}\left(\mathrm{R}_{\mathrm{t}}\right) *\left(\mathrm{Y}^{\mathrm{P}} / \mathrm{Y}\right)^{\varepsilon}
\end{gathered}
$$

\footnotetext{
${ }^{6}$ When the structural balance rule was announced for the first time in 2000, the long-term copper price was decided by the government. In the year 2002, and as way to enhance the rule's credibility, the government nominated an independent panel of experts to determine this price. The authorization to delegate on an independent panel the determination of the long-term copper prices was enshrined in the FRL enacted in 2006. This copper panel meets once a year to define the long-term copper price that determines the budget envelope for the following year.
} 
where $E\left(S R_{t}\right)$ will equal the expected government revenues $\left(E\left(R_{t}\right)\right)$ minus the expected adjustments for the long-term copper price and the output gap, $E\left(A_{t}\right) . Y^{p}$ is the potential output (that is the maximum output compatible, at any given time, with the absence of unexpected inflation), $\mathrm{Y}$ is the actual output and $\varepsilon$ is the elasticity of revenues with respect to the output gap. This methodology, as explained in Marcel, et al. (2001), was predicated on (i) the absence in Chile of public spending programs with a cyclical component; and (ii) the need to preserve the simplicity of the rule by focusing on the essential cyclical adjustments.

The expected fiscal outcomes are very sensitive to the estimates of structural revenues, which are unobservable. Under the rule, any overestimation of the structural revenues will translate into higher expenditures and a more expansionary fiscal stance. For instance, any overestimation of the long-term copper price by the panel of experts would translate into an increase in expenditures. This implies that the expenditure level, and the fiscal policy stance devised under the rule, becomes endogenous to changes in key parameters, such as the longterm copper prices and other exogenous factors not related to the copper price and the cycle (such as the exchange rate, copper production, and inflation).

\section{During 2001-04 the computation of the structural balance was relative easy to replicate.}

Initially copper prices were very stable, and the returns from the sovereign funds were small. ${ }^{7}$ In addition, given the large investment levels in the 1990s, private mining companies' reported large amortizations and low levels of profits and income tax (see Figure 2). Therefore, during these years, (see Velasco et al. (2010)), the copper price adjustment entailed mainly computing the physical sales of the national copper company (CODELCO) at the long-term copper price. The rest of revenues, including the taxes paid by private mining companies, were adjusted according to the output gap of the total GDP, in an aggregate way and following the IMF guidelines on the calculation of structural balance.

Figure 2. Chile: Copper Price Evolution and Composition of Mining Revenues
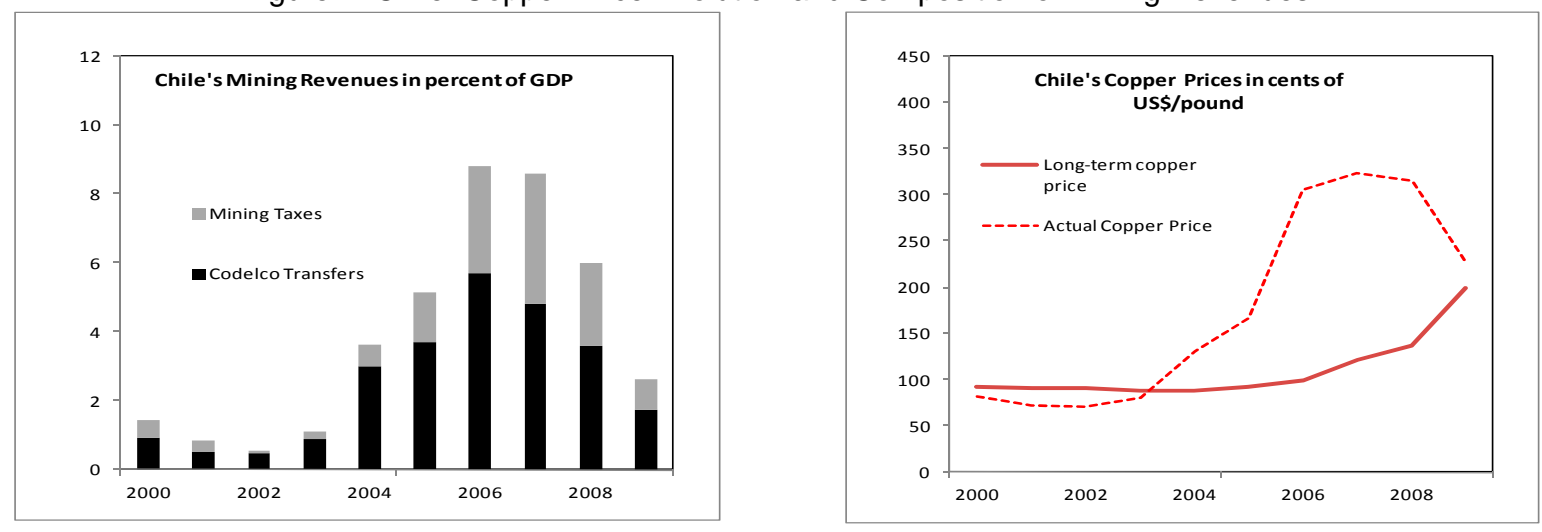

Sources: DIPRES and staff calculations.

\footnotetext{
${ }^{7}$ See Velasco et al. (2010). Returns from the sovereign funds in 2004 only accounted for 0.3 percent of total government revenues (or 0.1 percent of GDP).
} 
After 2005, the computation of the structural balance became quite challenging, as the
structure of the economy evolved. The main challenges derived from non-linear impact of soaring copper prices in mining tax collections, the introduction of new specific mining taxes, the coming into stream of the production of other minerals (e.g., molybdenum), and the increase in the return of the sovereign funds (which reached almost 4 percent of total revenues in 2008, reflecting an increase in the funds' balances and higher world interest rates). To avoid that these developments could translate into an increase in structural revenues, and therefore, into an increase in expenditure, the Budget Directorate included additional adjustments to the rule (see Table 2). These adjustments have rendered the methodology for the calculation of the structural balance difficult to replicate, and has opened the door for the introduction of discretionary adjustments. ${ }^{8}$

The authorities' willingness and ability to revise the methodology in an open way has been a facet of strength. The Budget Directorate has published ample and detailed information on the methodology for the computation of the structural balance, and all of its modifications. The Budget Directorate also publishes abundant information on the calculation, ex-ante and ex-post, of the structural balance. Publications include the actual values and projections of the overall balance along with the estimated cyclical components from which it is possible to derive the structural balance (see Table 3). The published information also readily allows for the calculation of other standard fiscal indicators, such as the primary balance.

Table 2. Chile: Modifications to the Methodology of Calculation of the Structural Balance, 2005-10

\begin{tabular}{ll}
\hline Type of Modification & Date \\
\hline Long-term copper price adjustment extended to income tax of mining companies & August 2005 \\
CODELCO's revenues adjusted by the long-term price of molybdenum & December 2005 \\
Long-term copper price adjustment extended to specific tax on mining & January 2006 \\
Long-term copper price adjustment extended to tax on repatriated profits of mining companies & December 2006 \\
Long-term copper price adjustment extended to advanced payments under the specific tax on mining & December 2007 \\
Adjustment of the sovereign funds' return according to an estimated "long-term interest rate" & September 2008 \\
$\begin{array}{l}\text { Exclusion of some transitory tax modifications } \\
\text { Elasticities of individual taxes were updated and applied item by item (according to OECD methodology for the } \\
\text { calculation of structural balance) }\end{array}$ & June 2009 \\
Non-mining non-tax revenues are also adjusted according to the output gap 2009 & January 2010 \\
\hline
\end{tabular}

Sources: Velasco et al. (2010) and Rodriguez, Tokman, and Vega (2007).

\footnotetext{
${ }^{8}$ The recalculation of the mining taxes under the long-term copper price is conducted separately for the currently existing three mining taxes, including the income tax, the tax on repatriated profits, and the specific mining tax, and for each of the main components of these taxes, including advanced payment, and return fillings (see Velasco et al., 2010).
} 
The assessment of Chile's fiscal policy focused almost exclusively on the structural balance, which at times has imparted an unintended procyclicality to government expenditures. The structural balance is not necessarily a good indicator of the impact of fiscal policy on domestic demand. A more informative indicator of the fiscal policy stance is the structural non-mining balance, defined as the structural non-mining revenues minus total expenditures (see Medas and Zakharova, 2009). An increase in the non-mining deficit would indicate an expansionary fiscal policy affected either through higher expenditure or a relaxation of non-mining revenue collections. By looking at the non-mining structural balance during 2000-08, a slightly different, yet complementary, assessment of Chile's fiscal performance emerges. During these years, the government's structural balance of 1 percent of GDP was equivalent to non-mining structural deficits that hovered around 0.8 and 1.8 percent of the nonmining GDP, implying that in certain years the structural balance rule could have imparted a sizeable fiscal impulse to the economy. In particular, during the boom years (2007-08), the non-mining structural deficit and the real rate of growth of expenditures increased significantly, even though the output gap was positive (see Figure 3). The increase in expenditures in 2008 partly reflected the discretionary reduction in the structural surplus target, for 1 percent of GDP to 0.5 percent of GDP, but also the upward revision in the expert-determined long-term price of copper and the increase in the return of the sovereign funds (which was part of structural revenues until 2009).

\section{The procyclicality of the rule may also have been driven by the absence of well-defined} provisions to handle ex-post deviations. The actual structural balance reported ex-post by the Budget Directorate (see Table 3) seems to indicate the implementation of end-of-the year adjustments to ensure the ex-post compliance with the rule. The fact that the Chilean government has in fact tried to comply ex-post with the target appear to have enhance the rule's credibility, but at the price of leading, at times, to procyclical fiscal tightening or loosening.

Table 3. Chile's Fiscal Balances

\begin{tabular}{|c|c|c|c|c|c|c|c|c|c|}
\hline \multicolumn{10}{|c|}{$\begin{array}{l}\text { Structural Balance, Non-Mining Structural Balance and Real Expenditure Growth } \\
\text { (In percent of GDP, unless otherwise noted) }\end{array}$} \\
\hline & 2001 & 2002 & 2003 & 2004 & 2005 & 2006 & 2007 & 2008 & 2009 \\
\hline Overall Balance & -0.5 & -1.2 & -0.2 & 2.1 & 4.6 & 7.7 & 8.8 & 5.2 & -4.4 \\
\hline Total cyclical adjustments & -1.5 & -1.9 & -1.2 & 1.1 & 3.6 & 6.7 & 7.8 & 4.6 & -2.7 \\
\hline Structural Non-Mining Taxes & -0.5 & -0.9 & -0.8 & -0.5 & -0.2 & -0.2 & -0.1 & 0.2 & -2.8 \\
\hline Copper Price & -1.0 & -1.0 & -0.4 & 1.6 & 3.8 & 6.9 & 7.9 & 3.4 & 0.6 \\
\hline Molybdenum Price & & & & & & & & 0.0 & 0.0 \\
\hline Private mining companies & & & & & & & & 1.0 & 0.0 \\
\hline Specific mining tax & & & & & & & & 0.0 & 0.0 \\
\hline Others & & & & & & & & 0.0 & -0.5 \\
\hline Structural Balance & 1.0 & 0.7 & 1.0 & 1.0 & 1.0 & 1.0 & 1.0 & 0.6 & -1.7 \\
\hline $\begin{array}{l}\text { Non-mining structural balance } \\
\text { (in percent of non-mining GDP) }\end{array}$ & -1.3 & -1.5 & -1.0 & -1.6 & -0.8 & -1.8 & 0.1 & -1.2 & -5.0 \\
\hline Real expenditure growth & 5.8 & 4.7 & 2.1 & 5.3 & 6.7 & 4.9 & 8.4 & 7.8 & 17.8 \\
\hline
\end{tabular}


Table 4. Assessment of Chile's Structural Balance Rule

\begin{tabular}{|c|c|c|}
\hline Best Practices & Design & Practical Implementation \\
\hline $\begin{array}{l}\text { - A (or several) clear and simple } \\
\text { numerical target(s) in terms of a } \\
\text { (or several) specific fiscal } \\
\text { indicator(s). } \\
\text { - A clear definition of the fiscal } \\
\text { objectives or challenges. } \\
\text { - An unambiguous and stable link } \\
\text { between the numerical targets or } \\
\text { ceilings and the ultimate fiscal } \\
\text { objectives. } \\
\text { Exceptional circumstances } \\
\text { clauses that allow for temporary } \\
\text { deviations in the face of a major } \\
\text { shock. } \\
\text { Well-defined mechanisms to deal } \\
\text { with ex-post deviations. } \\
\text { Provisions to undertake periodic } \\
\text { and rolling adjustments of the } \\
\text { numerical targets, if need be. } \\
\text { A clear statutory basis. } \\
\text { Effective monitoring and } \\
\text { transparency mechanisms }\end{array}$ & $\begin{array}{l}\text { - Yes; Chile's definition of structural balance is clear. } \\
\text { - Mixed; the rule aims at insulating expenditure from } \\
\text { transitory shocks; but the FRL does not specify the rule's } \\
\text { final objectives. It only focuses on the use of fiscal } \\
\text { surpluses. } \\
\text { - Mixed; the rule has (i) a focus on how each administration' } \\
\text { fiscal policy will contribute to achieve the annual structural } \\
\text { balance; and (ii) a weak connection with long-term fiscal } \\
\text { goals. } \\
\text { - No; the rule does not explicitly allow for a discretionary } \\
\text { countercyclical response, even in cases of large shocks. } \\
\text { - No; the rule does not specify whether compliance is ex- } \\
\text { ante or ex-post, or envisage any mechanism to correct ex- } \\
\text { post deviations. } \\
\text { Mixed; the rule is in principle very flexible because it does } \\
\text { not constraint the government's capacity to modify the } \\
\text { structural balance target, but it does not include any } \\
\text { guidance on circumstances under which changes can be } \\
\text { introduced. } \\
\text { Yes; the structural balance rule is supported by special } \\
\text { legislation, the Fiscal Responsibility Law (FRL). } \\
\text { No specific provisions envisaged in the FRL, except for the } \\
\text { obligation of the Budget Directorate to compute each year } \\
\text { the structural balance. } \\
\text { output gap; no independent authority verifies compliance } \\
\text { with the rule. }\end{array}$ & $\begin{array}{l}\text { - The computation has become very complicated in last } \\
\text { few years. } \\
\text { - The rationale and methodology of the rule is laid out } \\
\text { in policy papers published by the Budget Directorate. } \\
\text { - No quantitative long-term target for the government's } \\
\text { net financial wealth. Upward revisions in long-term } \\
\text { copper prices have imparted in certain years } \\
\text { procyclicality to government spending. } \\
\text { - In the absence of these exceptional clauses, the rule } \\
\text { has been the facto suspended in } 2010 \text {, because of } \\
\text { the earthquake in February. } \\
\text { The absence of mechanisms to handle ex-post } \\
\text { deviations has incentivized the implementation of } \\
\text { end-of-the year adjustments to ensure ex-post } \\
\text { compliance. } \\
\text { The target has been changed over time for various } \\
\text { reasons; although not required by the FRL, the } \\
\text { changes have been usually supported by detailed } \\
\text { analytical work. } \\
\text { - The FRL is very generic and does not include any } \\
\text { provision on transparency, accountability, exceptional } \\
\text { clauses, and ex-post deviations. } \\
\text { of its complexity, which reflects the authorities' efforts } \\
\text { to explain the performance under the rule. } \\
\text { strong responsiveness to new informational demands. } \\
\text { - }\end{array}$ \\
\hline
\end{tabular}


Figure 3: Chile's Key Fiscal Indicators
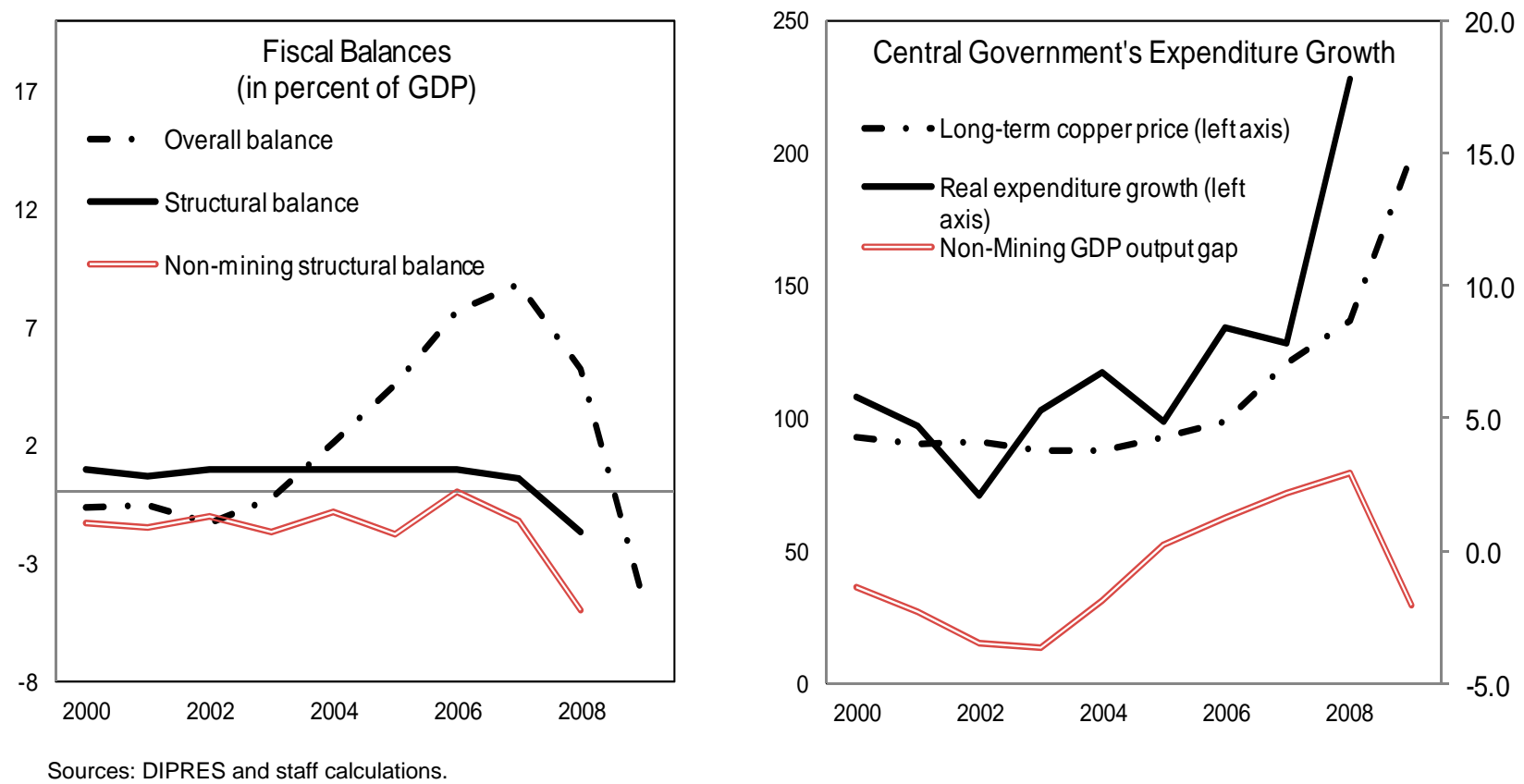

Chile's definition of the structural balance has no clear and straightforward link with any fiscal long-term objective. The fiscal indicator that is relevant to maintain the government's net financial position at a positive and sustainable level is the overall balance and not the structural balance as defined under the Chile's rule. So far, by targeting a structural surplus, Chile's government has managed to post large overall balances, especially during 2004-08, and has improved substantially its net financial position. However, targeting a structural surplus or balance is not a guarantee of achieving an overall surplus or balance. This could be illustrated with an extreme case of a sharp and large fall in the copper price. If the actual copper price falls suddenly below the long-term copper price, the government could post an overall deficit, while at the same time posting a structural surplus. Under this scenario, the fiscal policy will reduce the government's net financial position, while at the same time not violating the structural surplus target. ${ }^{9}$

\section{In spite of the absence of specific escape clauses, in practice the government has made} judicious changes to the structural balance target and clearly explained the rationale for them. Since its inception, the numerical targets for Chile's structural balance rule have been changed two times. In 2008 the government reduced the structural balance from the initial target of 1 percent of GDP established in 2001 to 0.5 percent of GDP, and further to zero percent of GDP in 2009. In spite of not being required by the FRL, these changes have been usually accompanied by detailed evidence that the changes (in both cases, a reduction in the structural surplus) would not jeopardize fiscal sustainability. For instance, in 2007 the

\footnotetext{
${ }^{9}$ A sharp and large fall in the price of copper could not necessary be a problem if the fall were purely transitory. However, empirical evidence shows the difficulties to distinguish ex-ante between permanent and transitory shocks.
} 
Budget Directorate issued a policy paper (see Engel, Marcel, and Meller (2007)) that notes that the reduction in the structural surplus undertaken in 2008 was justified as the government reached its objective for net financial assets. The reduction in 2009 was justified to allow for a countercyclical fiscal response to the global financial crisis. In 2010 the rule has been temporarily suspended after the earthquake in last February. In fact during 2009 and 2010, the rule de facto has been implemented in a different way, with expenditures determined by the government's immediate needs (and therefore not calculated as a residual as in previous years), and with the structural balance computed as the residual.

Despite its relative complexity, the structural balance rule, gives the public and markets important confidence-enhancing information about future macro-fiscal responses into the medium-term. The rule is very well known to the public and has helped signal the future behavior of the government (e.g., everybody expects that the central government will not increase expenditure in line with copper prices or GDP growth, see IMF 2003, 2005). The rule's credibility is strong also because of the government's decision to rely on two independent panels of experts to determine critical inputs for the estimation of the structural balance: the long-term copper price and the rates of growth of the labor force, capital accumulation, and total factor productivity. Statements identifying the members and documenting the panels' results are published by the Budget Directorate on a regular basis.

\section{How does Chile's structural balance rule compare to OECD practices?}

Like Chile, most OECD countries have rule-based fiscal frameworks. According to the OECD, 27 out of its 31 country members ${ }^{10}$ have a rule-based fiscal framework. The countries that do not have a rule-based fiscal framework are Japan, Korea, Turkey and the United States. In most of the cases, the fiscal rules are supported by specific national legislation, guidelines or supranational agreements, except for the cases of Greece, Ireland and the Slovak Republic, in which fiscal policy is only constrained by the EU rule-based framework. The rationales that OECD countries put forward for the adoption of a fiscal rule are very diverse and include a combination of objectives such as ensuring public debt sustainability, addressing common pool problems in highly decentralized countries or within international arrangements, restraining domestic demand expansions, and tackling future ageing-related spending needs. Although several OECD countries, as Chile, derive an important part of government revenues from natural resources, only two of them, Mexico and Norway, have adopted special mechanisms to manage these revenues.

In contrast with Chile's rule, which focuses only on one fiscal indicator, OECD countries' fiscal rules usually include a combination of fiscal indicators. The most common combinations are (i) fiscal rules that include an upper limit on gross or net public

\footnotetext{
${ }^{10}$ The 31 member countries of the OECD are: Australia, Austria, Belgium, Canada, Chile, Czech Republic, Denmark, Finland, France, Germany, Greece, Hungary, Iceland, Ireland, Italy, Japan, Korea, Luxembourg, Mexico, the Netherlands, New Zealand, Norway, Poland, Portugal, Slovak Republic, Spain, Sweden, Switzerland, Turkey, United Kingdom, and United States.
} 
debt or a desirable debt path and ceilings on one or several definitions of deficit (overall, structural balance, primary balance, and non-oil primary balance) (e.g., Maastricht Treaty and the Stability and Growth Pact); and (ii) fiscal rules that include ceilings for the overall balance and the level or the growth rate of expenditures (either in nominal or real terms) (e.g., Sweden, Finland, Netherlands) (see Appendix II). The rationale for combining several fiscal indicators derives from the difficulties of tackling at the same time, and with only one individual fiscal indicator, both sustainability and cyclicality issues. A few countries also complement their fiscal rules with borrowing rules (e.g., prohibition of central bank financing; "golden rules" according to which government borrowing must be equal to public investment) and revenues rules (e.g., caps on tax rates or rules to save revenues windfalls).

Most OECD fiscal rules are embedded in comprehensive institutional arrangements. These arrangements include fiscal responsibility laws; full-fledged medium-term fiscal and expenditure frameworks; well-defined escape clauses, which limit or suspend the application of the rule during exceptional circumstances; stringent transparency requirements; and special accountability mechanisms, such as the creation of non-partisan fiscal councils. In a few countries these institutional arrangements are even more important than the fiscal rule itself and some countries (New Zealand, Australia, and United Kingdom) do not even specify any numerical target. ${ }^{11}$ The relevance of these institutional arrangements responds to an increasing debate, among OECD countries, to consider rule-based fiscal frameworks as devices that seek (i) to maximize the reputational costs of breaching commitments but without formally restricting discretion; and (ii) to guide the public debate on fiscal policy, rather than put fiscal policy on automatic pilot (see Kumar and Ter-Minassian, (2007)). This debate has been driven by recent experience that shows that adequate institutional arrangements can deliver better fiscal outcomes than stand-alone mechanical numerical fiscal rules. ${ }^{12}$

\section{Options to Strengthen Chile’s Fiscal Rule}

The previous analysis suggests that Chile's structural balance rule would benefit from a few adjustments. The main areas for improvements could be: (i) simplifying the computation of the structural balance; (ii) avoiding any unintended procyclicality; (iii) adding a medium-term fiscal anchor; (iv) incorporating explicit escape clauses;

(v) strengthening the rule's monitoring and transparency mechanisms; and (vi) enhancing the rule's enforcement and accountability procedures.

\footnotetext{
${ }^{11}$ For instance, New Zealand's Fiscal responsibility Act aims at maintaining public debt at “prudent” levels by running appropriate operating balances. See Lienert (2010).

12 In this respect the analogy with the "rules versus discretion" debate as regards monetary policy is instructive. Central bank reforms, including inflation targeting, have not eliminated discretion. Instead they have sought to create a framework and provide clear institutional guarantees that discretion would not be misused. In other words, monetary policy rules aim at preserving the benefits of both discretion and rules without facing the costs of either of them (see Bernanke et al. (1999), Wyplosz (2008), and Kumar and Ter-Minassian (2007)).
} 
The methodology for the calculation of the structural balance needs to be easy to understand and replicate by independent third parties. One way to improve the methodology could be to adjust non-mining tax revenues for to the output gap of the nonmining GDP, instead of total GDP, which would also facilitate the estimation of more reasonable elasticities for each of the components of non-mining taxes vis-à-vis the cycle. Moreover, the structural balance target should be defined in primary terms, i.e., excluding net interest payment (interest payments minus interest receipts), and especially the sovereign funds' returns. In addition, the current methodology to adjust mining revenues, which implies the recalculation of individual components of mining taxes at the long-term copper price, could be simplified and the existing room for discretion could be minimized. As an illustration, structural mining revenues $\left(\mathrm{SR}_{\mathrm{t}}{ }^{\mathrm{m}}\right)$ could be computed by multiplying total mining revenues $\left(\mathrm{R}_{\mathrm{t}}^{\mathrm{m}}\right)$ by the ratio between the long-term and actual copper prices, according to the following formula:

$$
\mathrm{SR}_{\mathrm{t}}^{\mathrm{m}}=\mathrm{R}_{\mathrm{t}}^{\mathrm{m}} *[\text { Long-term Copper Price } / \text { /Actual Copper Price }]^{\gamma}
$$

where Long-term Copper Price ${ }_{\mathrm{t}}<$ Actual Copper Price $_{\mathrm{t}}$ and $\gamma$ is the estimated elasticity of mining revenues to the ratio of the actual copper price to the long-term copper price. Assuming that $\gamma=1$, Figure 4 shows that the profile and level of the structural mining revenues, and therefore expenditures, would have been broadly in line with the results obtained by using the methodology currently applied by the authorities.

Figure 4. Chile: Structural Copper Revenues and Expenditures Under Alternative Price-based Corrections
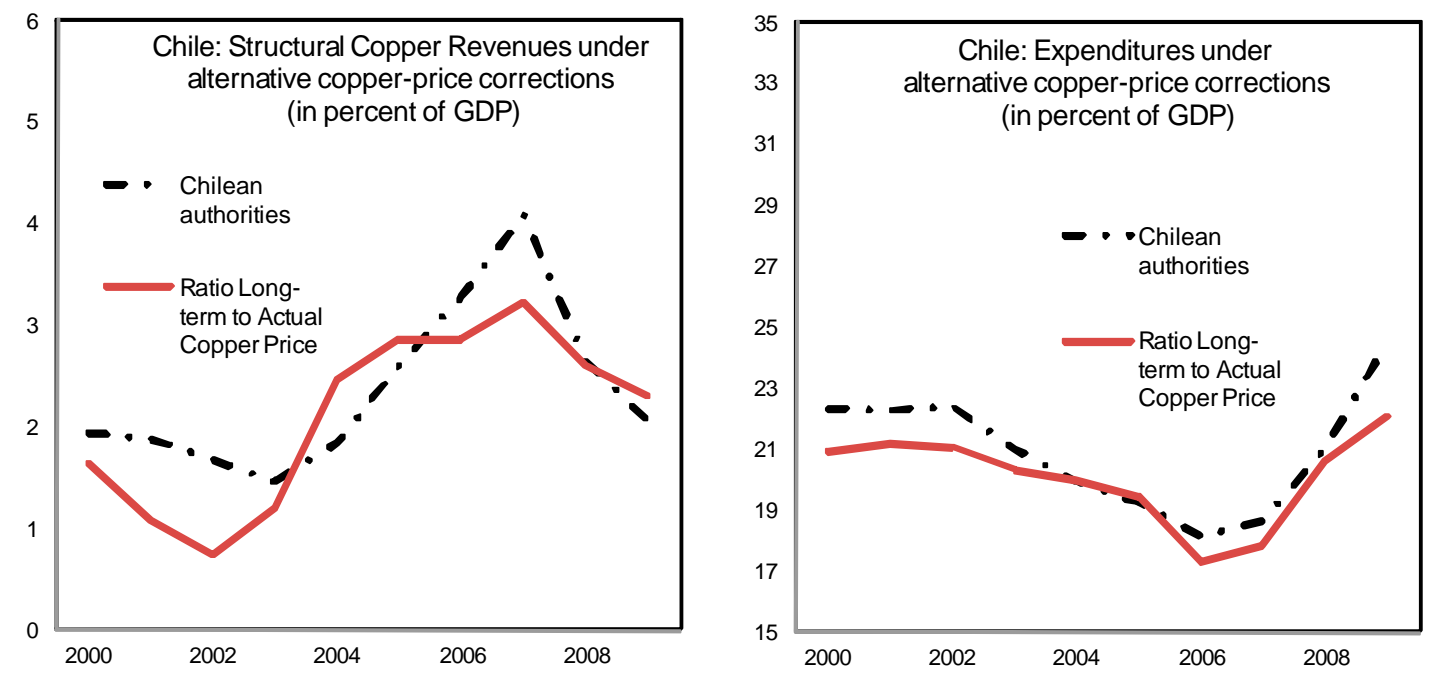

Sources: Authorities, Haver Analytics, and staff calculations.

Unintended procyclicality could be reduced. This can be done: by (i) capping the annual growth rate of government expenditures in real terms; (ii) publishing on a routine basis the calculation of the structural non-mining primary balance (as a percent of non-mining GDP); and (iii) adding provisions to handle ex-post deviations to avoid last-minute fiscal tightening or loosening at the end of the year to comply with the rule, similar to the provisions applied 
by Germany and Switzerland (see Table 5). For example, the expenditure level determined by the structural balance rule, $\mathrm{E}_{\mathrm{t}}$, could be considered as an upper limit. The ex-post deviations from the structural balance rule could be treated in the following way: (i) if the deviation is due to a larger ex-post level of structural revenues, the windfall will be saved, and the level of ex-post expenditure will be maintained at the initially planned level $E_{t}$; (ii) if the deviation is due to a lower level of ex-post structural revenues, and therefore a higher level of ex-post structural deficit, the ex-post level of expenditure could also be maintained at $E_{t}$. In this second case, the deviations in the structural balance could be stored in a notional account, with the obligation of adopting corrective actions in the next three years after the account reaches a certain level.

Table 5. Management of Ex-post Deviations from Fiscal Rules in Selected OECD Countries

\begin{tabular}{|c|c|c|}
\hline Country & Mechanism & Correction Actions \\
\hline Germany & $\begin{array}{l}\text { If the expost outturn of the structural balance } \\
\text { deviates from the } 0.35 \text { percent of GDP limit, the } \\
\text { (positive or negative) gap is stored on a notional } \\
\text { control account corrected from those errors } \\
\text { deriving from real GDP growth projections. }\end{array}$ & $\begin{array}{l}\text { If the notional account debit exceeds } \\
1.5 \text { percent of GDP, the authorities needs to } \\
\text { implement an adjustment. The adjustment only } \\
\text { needs to be launched during an economic } \\
\text { recovery to avoid a procyclical tightening. }\end{array}$ \\
\hline Switzerland & $\begin{array}{l}\text { Ex-ante expenditures are computed as predicted } \\
\text { revenues adjusted by the ratio of trend GDP to } \\
\text { expected real GDP. At the end of the year, the } \\
\text { expost expenditure ceiling is calculated by } \\
\text { multiplying the actual revenue by the ratio of } \\
\text { actual GDP to trend GDP. Any deviations of } \\
\text { actual spending from the calculated ex post } \\
\text { spending ceiling, independent of their cause, are } \\
\text { accumulated in a notional compensation account. }\end{array}$ & $\begin{array}{l}\text { If the negative balance in that account exceeds } \\
6 \text { percent of expenditures (about } 0.6 \text { percent of } \\
\text { GDP) the authorities are required by law to take } \\
\text { measures sufficient to reduce the balance below } \\
\text { this level within three years. }\end{array}$ \\
\hline
\end{tabular}

Source: IMF (2009).

The Chile's fiscal rule could be strengthened by including well-designed escape clauses. These clauses would define "exceptional circumstances" that would allow for temporary deviations in the face of a major shock. They should be limited to a short list (e.g., earthquake, the recent global crisis, a major demand imbalance under which the rule is declared in abeyance, see Table 6). They should also be precisely described with very limited discretion in interpreting events. An essential requirement also is to have pre-determined, credible and transparent procedural mechanisms (e.g., debate in congress) for the approval of the temporary departure from the rule. In addition, the rule should include provisions mandating the authorities to revise the government's medium-term fiscal framework in a way that would allow fiscal accounts to return back to the rule.

\section{The structural balance rule could benefit from the introduction of a long-term fiscal} anchor. The anchor could be established as a target (e.g., defined as a floor within a reasonable range) for the government's net financial wealth, which should be sufficient to cover existing contingent liabilities and provide the government with a buffer to counter unexpected shocks. This would require monitor the size of the overall balance on a routine basis as well as the number of consecutive overall deficits that will be allowed before 
modifying the numerical target of the structural balance. The achievement and monitoring of the long-term fiscal anchor could be supported by a full-fledged medium-term fiscal framework (MTFF), which will include rolling expenditures ceilings and non-mining revenues targets, long terms projections of copper revenues, and a full account of existing contingent liabilities. The MTFF could be subject to stress tests and sensitivity analysis, on a routine basis or under major changes in key parameters. The adoption of an MTFF is vital to limit, assess and correct ex-post deviations from the rule.

Table 6. Escape Clauses of Fiscal Rules in Selected OECD Countries

\begin{tabular}{|c|c|c|c|c|}
\hline Country & Rule & Triggering Factors & Triggering Mechanisms & Correction \\
\hline Spain (2001) & $\begin{array}{l}\text { All levels of } \\
\text { government must have } \\
\text { a balanced or in- } \\
\text { surplus budget }\end{array}$ & $\begin{array}{l}\text { Exceptional circumstances, } \\
\text { such as natural disasters; } \\
\text { downturns ( } 1 \text { percent of } \\
\text { GDP); periods of large public } \\
\text { investment ( } 0.5 \text { percent of } \\
\text { GDP). }\end{array}$ & Congress approval & $\begin{array}{l}\text { The delinquent } \\
\text { government } \\
\text { (region or central) } \\
\text { has to implement } \\
\text { a three-year } \\
\text { adjustment plan. }\end{array}$ \\
\hline Switzerland (2003) & $\begin{array}{l}\text { Cyclically adjusted } \\
\text { balanced budget }\end{array}$ & Exceptional circumstances & $\begin{array}{l}\text { Supermajority Congress } \\
\text { approval }\end{array}$ & $\begin{array}{l}\text { Medium-term } \\
\text { adjustment plan }\end{array}$ \\
\hline Germany (2009) & $\begin{array}{l}\text { Structural balance } \\
\text { budget must not } \\
\text { exceed } 0.35 \text { percent of } \\
\text { GDP }\end{array}$ & $\begin{array}{l}\text { Exceptional circumstances or } \\
\text { natural disasters }\end{array}$ & $\begin{array}{l}\text { Supermajority Congress } \\
\text { approval }\end{array}$ & Adjustment plan \\
\hline $\begin{array}{l}\text { Maastricht Treaty } \\
(1992) \text { and Stability } \\
\text { and Growth Pact } \\
(1997,2005)\end{array}$ & $\begin{array}{l}\text { Deficit and debt of } 3 \\
\text { and } 60 \text { percent of } \\
\text { GDP; close to balance } \\
\text { or in surplus structural } \\
\text { balance. }\end{array}$ & $\begin{array}{l}\text { Real GDP had decreased } \\
\text { annually by at least } \\
2 \text { percent. }\end{array}$ & $\begin{array}{l}\text { Verification by European } \\
\text { authorities. }\end{array}$ & $\begin{array}{l}\text { A medium-term } \\
\text { adjustment plan }\end{array}$ \\
\hline
\end{tabular}

Sources: Kumar and Ter-Minassian (2007) and IMF (2009).

The transparency mechanisms of Chile's fiscal rule could also be enhanced. Although not required by the FRL, the government provides the public with a large amount of high quality and relatively opportune information on budget formulation, execution and the performance under the structural rule. However, information is presented in a large number of documents that are difficult to reconcile. In addition, a consolidated assessment of the government's assets and liabilities, and reconciliation with key flows, is not provided on a regular basis. Reforms should focus on reflecting in a legal document (e.g., a supreme decree) a set of well-defined transparency provisions so that they become permanent components of Chile's fiscal framework, rather than depending on the goodwill of governments. The provisions should outline: (i) a clear calendar for fiscal reporting; (ii) the scope and contents of reports; and (iii) a clear mandate for the fiscal reports to include the financial statements and net asset position of public enterprises, the central bank and other public institutions and the consolidated net financial position of the government.

\section{The rule's accountability mechanisms could be strengthened, by expanding the} mandate of the current panels of experts, and transforming them into an independent fiscal council (FPC). The adoption of a FPC is a reform that delegates part of the policy makers' mandate to an independent and specialized body. Cross-country experience shows that this type of reform usually occurs slowly and encounters stiff opposition. However, a 
variety of FPCs operates in a number of countries (see Table 7) and seems to have contributed to fiscal discipline (see Kumar and Ter-Minassian (2007)). Country experience also shows that the desirable mandate and set up of FPC should be country specific. Chile could take advantage of its successful experience with the adoption of independent bodies such as the central bank's independent Monetary Policy Committee and the two panels of experts that aid in the implementation of the structural balance rule. The FPC could provide: (i) objective analysis of current fiscal policy; (ii) independent projections and forecasts of key macrofiscal variables; and (iii) an assessment on the application of the rule, including by providing an opinion in the case the escape clauses are evoked and suggesting corrective actions. The FPC would have only an advisory role, with the final decision made by the government and congress, and should be accountable to the legislative branch.

Table 7. Fiscal Councils in Selected OECD Countries

\begin{tabular}{|c|c|c|c|}
\hline Country & Governance & Mandate & Accountability \\
\hline $\begin{array}{l}\text { U.S., Congressional Budget } \\
\text { Office (CBO), established } \\
\text { in } 1975,230 \text { full staff. }\end{array}$ & $\begin{array}{l}\text { The CBO director is appointed } \\
\text { jointly by the House of } \\
\text { Representatives and the Senate } \\
\text { and can be removed by either } \\
\text { house of Congress. He/she is } \\
\text { appointed solely on his/her } \\
\text { professional competence, without } \\
\text { regard to political affiliation. }\end{array}$ & $\begin{array}{l}\text { Advises Congress and } \\
\text { the public on fiscal issues, } \\
\text { assesses budget laws, } \\
\text { monitors budget } \\
\text { execution, and estimates } \\
\text { fiscal impact of draft laws. }\end{array}$ & $\begin{array}{l}\text { Congress; the CBO senior } \\
\text { staff regularly testifies } \\
\text { before Congress }\end{array}$ \\
\hline $\begin{array}{l}\text { Germany, Working Group } \\
\text { on Tax Estimates, } \\
\text { since } 1950 .\end{array}$ & $\begin{array}{l}\text { Representatives of federal and } \\
\text { Laender administration, central } \\
\text { bank, and biggest think tanks, } \\
\text { appointed by the Ministry of } \\
\text { Finance. }\end{array}$ & $\begin{array}{l}\text { Publishes regular } \\
\text { estimates of government } \\
\text { revenues }\end{array}$ & $\begin{array}{l}\text { Federal and Laender } \\
\text { governments }\end{array}$ \\
\hline $\begin{array}{l}\text { Netherlands, Central } \\
\text { Planning Bureau (CPB), } \\
\text { since 1945, } 170 \text { full time } \\
\text { staff. }\end{array}$ & $\begin{array}{l}\text { Board of Directors appointed by } \\
\text { the Minister of Economic Affairs in } \\
\text { consultation with key economic line } \\
\text { ministries. }\end{array}$ & $\begin{array}{l}\text { Provides the economic } \\
\text { assumptions for the } \\
\text { budget and undertakes } \\
\text { research on budget } \\
\text { issues. }\end{array}$ & $\begin{array}{l}\text { The CPB is a public entity. } \\
\text { Subsequent ministries } \\
\text { have respected and } \\
\text { preserved the CPB's } \\
\text { independence. }\end{array}$ \\
\hline $\begin{array}{l}\text { Korea, National Assembly } \\
\text { Budget Office, } 92 \text { full time } \\
\text { staff }\end{array}$ & $\begin{array}{l}\text { Head appointed by Congress; the } \\
\text { head appoints other staff solely on } \\
\text { professional competence, not } \\
\text { political affiliation. }\end{array}$ & $\begin{array}{l}\text { Advises Congress on } \\
\text { fiscal policy issues; } \\
\text { analyzes budget policies, } \\
\text { estimates fiscal impact of } \\
\text { draft laws, and conducts } \\
\text { research. }\end{array}$ & Congress \\
\hline $\begin{array}{l}\text { Japan, Fiscal System } \\
\text { Council }\end{array}$ & $\begin{array}{l}\text { It is an entity of the Ministry of } \\
\text { Finance; composed of scholars, } \\
\text { governor of the central bank, } \\
\text { journalists, and business } \\
\text { executives. }\end{array}$ & $\begin{array}{l}\text { Advises the Ministry of } \\
\text { Finance on fiscal policy } \\
\text { and accounting issues. }\end{array}$ & $\begin{array}{l}\text { It has big influence on } \\
\text { budget formulation ideals } \\
\text { and process; accountable } \\
\text { to the Ministry of Finance. }\end{array}$ \\
\hline
\end{tabular}

Sources: Kumar and Ter-Minassian (2007) and web pages of the selected fiscal councils.

\section{Looking ahead, the structural balance rule could envisage a cyclical adjustment on the} expenditure side. At present, no cyclical adjustment is made to the expenditure side, because of the limited size of spending programs with a cyclical component, such as unemployment benefits. However, these programs could increase in size over time, which will translate into an increase in the size of the automatic stabilizers of Chile's budget as well. Larger automatic 
stabilizers would strengthen the structural balance rule's powers to minimize business cycle volatility and minimize the need for discretionary fiscal actions (see Kumhof and Laxton (2010)).

\section{CONCLUSIONS AND SUMmARY}

Chile has a broadly well-designed fiscal system, a strong reputation of prudent fiscal management, and an enviable fiscal position. The cornerstone of Chile's impressive fiscal performance and strong fiscal system has been its structural balance rule. Since its inception in 2001, the rule has helped to preserve fiscal discipline, while leaving room for countercyclical policies. It has helped to insulate public spending from copper price cycles and improve the government's net financial position. In addition, the structural balance rule has proved to be an effective communication tool of Chile's fiscal policy.

Nonetheless, the rule could be strengthened in several ways. The improvements should envisage: (i) the simplification of the calculation of the structural balance; (ii) the adoption of well-designed escape clauses to allow discretionary responses to negative shocks; (iii) the minimization of the rule's unintended procyclicality by incorporating provisions to deal with temporary ex-post deviations and capping the rate of growth of expenditures, especially in the context of sharp upward revisions in the long-term copper price; (iv) the introduction of an explicit long-term fiscal anchor, (e.g., in terms of a target for the government's net financial position); (v) the institutionalization and strengthening of the transparency practices currently used by the Chilean authorities, by specifying them in a legal document, such as a supreme decree and expanding its coverage; and (vi) extending the scope and mandate of the panels of experts beyond their current responsibilities, by allowing them to provide an objective analysis of current fiscal policy and assess compliance with rule.

In addition, Chile's authorities could seize this opportunity to strengthen their fiscal policy framework on a comprehensive way, beyond the strengthening of the fiscal rule, and in line with OECD countries. Chile should adopt a full-fledged medium-term fiscal framework to improve fiscal planning and provide a framework for addressing temporary deviations from the fiscal rule. Publishing additional fiscal indicators in the budget, such as the non-mining structural balance, could provide more comprehensive information on the impact of fiscal policy on the domestic demand.

The work of the Commission of Experts for the revision of the fiscal rule is progressing well. The Commission has so far produced a preliminary report (see Comité Asesor, 2010) that identifies most of the shortcomings and challenges pointed in this paper. The preliminary report, in addition, proposes a few methodological improvements in the calculation of the structural balance to be implemented immediately in the 2011 budget and provides a recalculation of the structural balance during the period 2001-2010 according to the new methodology. The Commission is expected to release its final report to the public in the first part of 2010. 


\section{REFERENCES}

Bernanke, B, S., Laubach, T., Misnkin, F.S. and Posen, A.S., 1999, Inflation Targeting lessons from International Experience, Princeton University Press, Princeton.

Blondal, J. and Curristine, T., 2004, “Budgeting in Chile,” Journal on Budgeting, Volume 4, No 2, OECD, Paris.

Comité Asesor para el Diseño de Una Política Fiscal de Balance Estructural de Segunda Generación, Primer Informe, 2010, Santiago de Chile.

Dirección de presupuestos (DIPRES), 2009, Informe de Pasivos Contingentes, Ministerio de Hacienda, Gobierno de Chile, Noviembre 2009, Santiago de Chile.

Fiess, N, 2001, “Chile’s New Fiscal Rule” (Washington: The World Bank Group)

Gajardo M. and Vivallo,W., 2009, Evolución de las Reservas y Recursos de Cobre, Molibdeno, Oro, Plata Nitrato y Yodo en Chile, 2001-2007, Servicio Nacional de Geología y Minería, Gobierno de Chile.

International Monetary Fund, 2009, "Fiscal Rules: Anchoring Expectations for Sustainable Public Finances,” Fiscal Affairs Department (Washington: International Monetary Fund).

, 2005, "Update of Chile: Report on Observance of Standards and Codes-Fiscal Transparency” (Washington: International Monetary Fund). , 2003, "Chile: Report on Observance of Standards and Codes_Fiscal Transparency” (Washington: International Monetary Fund).

Kopits, G. and S. Symansky, 1998, “Fiscal Policy Rules,” Occasional Paper No. 162 (Washington: International Monetary Fund).

Kumar, M.S. and Ter-minassian, T., 2007, Promoting Fiscal Discipline (Washington: International Monetary Fund).

Kumhof, M. and Laxton, D., 2010, “Simple Fiscal Policy Rules for Small Open Economies” (mimeo).

Lienert, I, 2010, "Why most Advanced Countries Have Not Adopted a Fiscal Responsibility Law?” Working Paper (Washington: International Monetary Fund) (mimeo).

Marcel, M. Tokman, M, Valdes, R., and Benavides, P., 2001, "Methodology and Estimation for the Chilean Central Government 1987-2001,” Direccion de Presupuestos, Ministerio de Hacienda. 
Medas, P and Zakharova, D., 2009, “A Primer on Fiscal Analysis in Oil-Producing Countries,” Working Paper No. 09/56 (Washington: International Monetary Fund).

Rodriguez, J. Tokman, C. and Vega A., 2007, “Structural Balance Policy in Chile”, Journal on Budgeting, Volume 7-No.2 OECD, Paris.

Velasco, A, Arenas de Mesa, A, Rodríguez, J, Jorrat M, Gamboni, C., 2010, “El Enfoque de Balance Estructural en la Política Fiscal en Chile: Resultados, Metodologías y Aplicación al Periodo 2006-09”, Estudios de Finanzas Públicas, Dirección de Presupuestos, Ministerio de Hacienda.

Wyplosz, C., 2008, “Fiscal Policy Councils: Unlovable or just Unloved?” Swedish Economic Policy Review, 15, 2008. 


\section{APPENDiX 1. Chile’s COPPER Sector}

At present Chile is the world's largest copper producer, with an annual production of 5.5 millions of metric tons, which accounts for over 40 percent of world production. Within the Chilean economy, copper accounts for 45 percent of exports. Chile sells 35 percent of its copper to China, followed by Europe (20 percent), the U.S. (81/2 percent) and South Korea (81/2 percent). Mineral resources belong to the State that exploits them either through the State-owned enterprise CODELCO, which remains one of the country's largest copper producers (30 percent of Chile's total production) and a regime of concessions and joint ventures with private firms, most of them foreign.

As a result, copper production remains one of the most important sources of revenues for the government. Chile's tax regime on mining activities include (i) a small profit-related royalty, introduced in 2005, (ii) the standard corporate income tax, which is levied on all mining companies, included CODELCO; and (iii) the transfer of CODELCO to the central government budget. During 1987-2001, on average, copper revenues accounted only for 21/2 percent of GDP. However, during 2001-09, reflecting increasing copper production, but above all increasing copper prices, copper revenues reached almost 5 percent of GDP.

Prospects of Chile's copper sector remain positive, given the large volume of existing reserves and expectation of increasing global demand. Chile hosts about 30 percent of the world known copper sub-soil assets. According to the most recent official information (see Evolución de las Reservas y Recursos de Cobre, Molibdeno, Oro, Plata Nitrato y Yodo en Chile, 2001-2007, by M. Gajardo and W. Vivallo, Servicio Nacional de Geología y Minería, Gobierno de Chile, 2009), Chile’s total sub-soil copper assets amounted to 368 millions of metric tons in 2007, which are estimated to last for 63 years if the current annual production of 5.5 millions of metric tons is maintained. Due to the expected sustained increase in copper prices and demand, Chile's copper production is expected to expand further in the next few years. 


\section{APPENDiX 2. ChILE's Fiscal RUle FROM AN OECD PERSPECTIVE}

\section{Compared to practices in other OECD economies, Chile's fiscal rule presents several} strengths, but also some shortcomings. The differences between Chile's fiscal rule, and the practices in the other 27 OECD economies that have a fiscal rule could be usefully grouped in the seven categories listed below:

\begin{tabular}{|c|c|c|}
\hline & OECD Practices & Chile's Fiscal Rule \\
\hline $\begin{array}{l}\text { Clear statutory } \\
\text { basis }\end{array}$ & $\begin{array}{l}\text { In most OECD countries fiscal rules are } \\
\text { supported by special legislation } \\
\text { (e.g. national law, guidelines or } \\
\text { supranational agreements) that usually } \\
\text { includes stringent procedural rules on } \\
\text { accountability, transparency and fiscal } \\
\text { stability, as well as key budget principles. }\end{array}$ & $\begin{array}{l}\text { Chile's Fiscal Responsibility Law (FRL) of } \\
2006 \text { does not provide much guidance on the } \\
\text { design and practical implementation of the } \\
\text { fiscal. The FRL only mandates (i) that the } \\
\text { President of the Republic enacts, within the } 90 \\
\text { days of entering office, a decree indicating } \\
\text { how the fiscal policy planned for his/her } \\
\text { administration will affect the structural } \\
\text { balance; and (ii) that the Budget Directorate } \\
\text { calculates the structural balance. The nature, } \\
\text { rationale, and methodology for the calculation } \\
\text { of the structural balance rule have been } \\
\text { usually explained in policy papers issued by } \\
\text { the Budget Directorate. }\end{array}$ \\
\hline Clear targets & $\begin{array}{l}\text { The legislation on fiscal rules in most } \\
\text { OECD countries typically includes clear } \\
\text { methodological principles and definitions } \\
\text { for the fiscal covered by the rule; normally, } \\
\text { these comprise targets on gross or net public } \\
\text { debt, on several definitions of deficit } \\
\text { (overall, structural balance, primary } \\
\text { balance, non-oil primary balance), on tax } \\
\text { ratios, and on the growth rate of government } \\
\text { expenditure. }\end{array}$ & $\begin{array}{l}\text { Chile's FRL defines the structural balance, as } \\
\text { the difference between the central government } \\
\text { revenues and expenditures that would have } \\
\text { been obtained if, in any given year, the } \\
\text { economy was operating at potential and the } \\
\text { copper price was at its (estimated) long-term } \\
\text { level. The initial methodology outlined by the } \\
\text { Budget Directorate to calculate the structural } \\
\text { balance was easy to understand and replicate. } \\
\text { However, the computation of the structural } \\
\text { balance has became increasingly complex and } \\
\text { difficult to replicate over the years owing to } \\
\text { the expansion of the private mining sector, the } \\
\text { introduction of new taxes on mining, the } \\
\text { coming into stream of output of non-copper } \\
\text { minerals (e.g. molybdenum), and non- } \\
\text { transparent changes in the elasticities of tax } \\
\text { collections with respect to the output gap. }\end{array}$ \\
\hline $\begin{array}{l}\text { Clear } \\
\text { objectives }\end{array}$ & $\begin{array}{l}\text { The rationale for fiscal rules is usually } \\
\text { spelled out clearly in special legislation or } \\
\text { guidelines. The objectives of fiscal rules in } \\
\text { OECD countries typically include ensuring } \\
\text { public debt sustainability, addressing } \\
\text { common pool problems in highly } \\
\text { decentralized countries or within }\end{array}$ & $\begin{array}{l}\text { A } 2001 \text { policy paper of the Budget Directorate } \\
\text { spelled out the objectives of Chile's fiscal } \\
\text { rule. The paper noted that the structural } \\
\text { surplus targeted with the rule ( } 1 \text { percent of } \\
\text { GDP at the time) was to be used to } \\
\text { recapitalize the central bank, pre-finance } \\
\text { contingent liabilities, and create a buffer of net }\end{array}$ \\
\hline
\end{tabular}




\begin{tabular}{|c|c|c|}
\hline & OECD Practices & Chile's Fiscal Rule \\
\hline & $\begin{array}{l}\text { international arrangements, avoiding } \\
\text { domestic demand pressures, and tackling } \\
\text { ageing-related issues. }\end{array}$ & $\begin{array}{l}\text { financial assets to allow the central } \\
\text { government to absorb external shocks. The } \\
2006 \text { FRL, however, did not refer to these } \\
\text { objectives, and only stipulated the creation of } \\
\text { two separate sovereign funds for the allocation } \\
\text { of overall surpluses. }\end{array}$ \\
\hline $\begin{array}{l}\text { Clear link } \\
\text { between } \\
\text { targets and } \\
\text { objectives }\end{array}$ & $\begin{array}{l}\text { Fiscal rules in OECD countries usually set } \\
\text { targets/benchmarks on several fiscal } \\
\text { indicators covering both sustainability and } \\
\text { cyclicality aspects of fiscal policy. The most } \\
\text { common are (i) an upper limit on gross or } \\
\text { net public debt and ceilings on one or } \\
\text { several definitions of deficit (e.g. Maastricht } \\
\text { Treaty and the Stability and Growth Pact); } \\
\text { and (ii) ceilings for the overall balance and } \\
\text { the growth rate of expenditures, either in } \\
\text { nominal or real terms (e.g. Sweden, Finland, } \\
\text { Netherlands). }\end{array}$ & $\begin{array}{l}\text { Chile’s structural balance rule does not } \\
\text { establish a clear link with medium-term fiscal } \\
\text { goals. The rule is not formulated within a full- } \\
\text { fledged medium-term framework nor is it used } \\
\text { to assess how current policies would affect the } \\
\text { government's net financial wealth. Moreover, } \\
\text { the upward revision of the long-term copper } \\
\text { price in recent years has imparted an } \\
\text { unintended procyclicality to government } \\
\text { expenditures. }\end{array}$ \\
\hline Flexibility & $\begin{array}{l}\text { Fiscal rules in most OECD countries } \\
\text { include provisions to deal with unexpected } \\
\text { shocks. These provisions allow temporary } \\
\text { deviations from the targets and provide } \\
\text { guidance for a gradual adjustment to those } \\
\text { targets, while avoiding procyclicatlity and } \\
\text { preserving credibility. The most common } \\
\text { provisions include: (i) “exceptional } \\
\text { circumstances clauses” that allow for } \\
\text { temporary deviations in the face of major } \\
\text { shocks; (ii) "notional accounts” to store } \\
\text { small ex-post deviations, which would be } \\
\text { corrected overtime (e.g. Germany and } \\
\text { Switzerland); and (iii) clear procedures to } \\
\text { undertake periodic and rolling adjustments } \\
\text { of the numerical targets. }\end{array}$ & $\begin{array}{l}\text { Chile's rule is, in principle, quite flexible, as it } \\
\text { does not constrain the government's capacity } \\
\text { to modify the structural balance target. In fact } \\
\text { the target has been changed over time for } \\
\text { several reasons, and the changes have been } \\
\text { usually justified by analytical work. However, } \\
\text { Chile's fiscal framework does not provide } \\
\text { much guidance on how to introduce changes } \\
\text { to the target or how to implement a } \\
\text { discretionary response to a shock. In terms of } \\
\text { ex-post compliance, Chile's FRL does not } \\
\text { contain mechanisms to assess small ex-post } \\
\text { deviations or eliminate them over time. }\end{array}$ \\
\hline $\begin{array}{l}\text { Transparency } \\
\text { provisions }\end{array}$ & $\begin{array}{l}\text { OECD legislation on fiscal rules usually } \\
\text { contains provisions to promote full } \\
\text { transparency of fiscal policy plans and ex- } \\
\text { post fiscal performance. Through these } \\
\text { provisions the public is generally well } \\
\text { informed of deviations and of plans to } \\
\text { correct them over time. }\end{array}$ & $\begin{array}{l}\text { Chile's FRL does not include provisions to } \\
\text { promote full transparency (either of the ex- } \\
\text { ante calculation of the structural balance or } \\
\text { ex-post performance). The only requirement is } \\
\text { that the Budget Directorate computes the } \\
\text { structural balance every year. The government } \\
\text { monitors fiscal performance on an ongoing } \\
\text { basis and has showed a strong responsiveness } \\
\text { to new informational demands, even though } \\
\text { not required by law. Because of those actions, } \\
\text { understanding of Chile's rule by the public is } \\
\text { quite high, in spite of its complexity. }\end{array}$ \\
\hline
\end{tabular}




\begin{tabular}{|l|l|l|}
\hline \multicolumn{1}{|c|}{ OECD Practices } & \multicolumn{1}{|c|}{ Chile's Fiscal Rule } \\
\hline Accountability. & $\begin{array}{l}\text { A large number of OECD countries have } \\
\text { created independent fiscal councils to } \\
\text { provide independent fiscal policy analysis } \\
\text { and recommendations. The councils usually } \\
\text { provide: (i) objective analysis of current } \\
\text { fiscal policy; (ii) independent projections } \\
\text { and forecasts of key macrofiscal variables; } \\
\text { and (iii) an assessment on the application of } \\
\text { the rule, and the quality of the fiscal } \\
\text { adjustment to comply. Typically, the } \\
\text { councils only have an advisory role, and are } \\
\text { accountable to the legislative branch. } \\
\text { independent panels of experts the } \\
\text { calculation of the structural balance (the long- } \\
\text { term copper price, and the rates of growth of } \\
\text { the labor force, capital accumulation, and total } \\
\text { factor productivity). The composition of the } \\
\text { panels and their main recommendations are } \\
\text { published by the Budget Directorate on a } \\
\text { regular basis. However, the recommendations } \\
\text { of the panels are not binding, and the law does } \\
\text { not assign to any third party the task of } \\
\text { assessing compliance with the rule. }\end{array}$ \\
\hline
\end{tabular}

